\title{
Understanding jökulhlaups: from tale to theory
}

\author{
Helgi BJÖRNSSON \\ Institute of Earth Sciences, University of Iceland, Askja, Sturlugata 7, IS-101 Reykjavík, Iceland
}

\begin{abstract}
The study of jökulhlaups has advanced from describing them qualitatively to measuring systematically on site their discharge curves and source geometry, as well as investigating conditions when particular floods were initiated. In the early days of this science, hypotheses were formulated which attempted to explain the processes responsible for unstable flood growth. The general theory of time-dependent turbulent water flow through intraglacial conduits marked a breakthrough in understanding jökulhlaup hydraulics and has since remained a classical foundation for jökulhlaup studies. This theory described flood evolution in terms of water input into the upper end of a tunnel leading from a reservoir, taking account of sensible stored lake heat and geometry. Such a tunnel expands by positive feedback, since its ice walls melt through frictional heat produced by the flowing water. While this model successfully described jökulhlaups in which the discharge hydrograph increases more or less exponentially over time, other floods were observed which are in stark contrast. In them, pressurized floodwater propagates in a turbulent subglacial water sheet which opens and expands a system of conduits, with an extremely rapid linear rise in discharge. The rushing water enlarges its subglacial pathway not only by melting the ice around it but also by lifting, deforming and fracturing it. Subsequent drainage is nourished by two different sources, with conduit growth being controlled not only by water input at the upper end of the flood path but also by further water joining in, all the way to the edge of the glacier. Moreover, the trigger for releasing meltwater from glacial lakes has been seen to be either of two conduit opening mechanisms, which also determine whether a turbulent subglacial water sheet will result or not. On the one hand, drainage may begin by expanding already existing conduits, in which case the pressure remains lower than that of the ice overburden at the dam and the conduits grow slowly. On the other hand, lake levels may rise until flotation of the ice dam, abruptly opening a sufficient gap for water to propagate as a sheet flow. In order to explain which of these two initiation mechanisms will act, further studies are required into the structure of hydrological drainage systems under ice dams and into their linkage with these two mechanisms. Although current theoretical models of jökulhlaup drainage have managed to reproduce the observed discharge patterns, inconsistencies with the observed behaviour of subglacial drainage systems along the flood path demand further exploration of the actual hydraulic and glaciodynamic processes of jökulhlaups.
\end{abstract}

\section{INTRODUCTION}

Progress in understanding jökulhlaups has followed the conventional path of scientific discovery. At first consisting of incidental observations and qualitative descriptions, the subject came into its own in the 1950s, as systematic collections of field observations yielded quantitative data amenable to the formulation and testing of hypotheses. Such hypotheses related field measurements to general physical principles, and ultimately an explanatory theoretical framework was produced which integrated the pieces into a comprehensive whole.

Despite these advances, nature has continued to reveal its complexity. Improved monitoring techniques, high-resolution data and continuing jökulhlaup occurrences, including the benefits of less common events, have indicated a richer flood variety than was previously recognized, and exposed shortcomings even in today's models. Thus the need for a clarifying, all-encompassing theory persists. The purpose of this paper is briefly to review the history of jökulhlaup science, from its first steps to the present understanding of glacial flood physics. While the treatment is influenced by the author's direct experience of Iceland, this is justified by that country's significant role in jökulhlaup discoveries.

Until the mid-20th century, the concept of jökulhlaups was based on piecemeal accounts from glaciated areas, including the Alps, Alaska, Canada, Iceland, New Zealand and Norway, along with sites in South America and the Himalaya, as well as being based on indications of water drainage from lakes at the edges of downwasting Pleistocene ice sheets (e.g. Stotter, 1846; Richter, 1892; Strøm, 1938; Thórarinsson, 1939; Liestøl, 1956; Gilbert, 1971; Post and Mayo, 1971; Baker, 1973; Bezinge and others, 1973; Mathews, 1973). Jökulhlaups were recognized as originating from marginal or subglacial sources of water which had been melted from the ice by atmospheric processes, geothermal influx or volcanic eruptions. Historical accounts were sometimes available, because floods of the jökulhlaup sort had in various cases brought destruction to inhabited regions. In some places jökulhlaups were known to strike repeatedly, normally from the same source but occasionally from other sources. Nonetheless, adequate knowledge of the physical conditions of jökulhlaup origins and of subglacial flow paths seldom existed, and no flood discharge rates had ever been exactly recorded.

Since the early 1970s, however, science has accumulated a great deal more information on jökulhlaup sources, the shape of their discharge curves and the amounts of water emitted. This has led to a clearer understanding of the nature of such floods, both through observation and the application of general physics. While much has thus been achieved, science still needs to explore many challenging problems regarding jökulhlaups. 


\section{DEDUCING JÖKULHLAUP HYDROGRAPHS}

In the early days of this science, the most detailed information on flood patterns had been gathered in the European Alps, Alaska, Canada, Iceland and Norway. However, obtaining accurate hydrographs that would support the study of drainage mechanisms inside the glacier was problematic not only then but even today. Conventional stream-gauging stations seldom existed at favourable positions for recording extreme floods, and even in those cases where jökulhlaups have been gauged, hardly any precise curves have yet been constructed that would relate stage and discharge at extreme flow. Direct on-site measurements of flood discharge rates at the glacier terminus were generally lacking during the high-water stages of any specific jökulhlaup, and flood path geometry was generally uncertain. Therefore, surrogate estimates of stream velocity were derived by hydraulic calculations (e.g. Pardee, 1942; Rist, 1955; Baker, 1973) based on the Gauckler-Manning equation (e.g. Chow, 1959). This equation, developed empirically for open, channelized waterways, relates energy dissipation to flood path roughness. In such an approximation, the observed surface slope at high water serves as a reference for calculating the energy slope. Even so, by the time a jökulhlaup is finished, the shape of its path will have been modified by erosion, and sedimentation in the flood's concluding stages will also have changed the channel cross section as well as its roughness. In order to reconstruct maximum flood stages, scientists thus depended on less direct evidence. Some of this they gathered by locating water divides where floodwater managed to spill over cols, seeking the highest flotation elevations of the largest iceencased boulders which drifted downstream (i.e. of the larger ice-rafted erratics), and by inspecting erosion along channel margins.

Even though a number of jökulhlaups have in fact been gauged in rivers some distance downstream from the glacier terminus, the flood wave may by that point have been significantly attenuated by passing through valleys, lakes and braided channels. This applies to many of the oldest hydrographs referred to in relation to jökulhlaups (e.g. Liestøl, 1956; Gilbert, 1971, 1972; Post and Mayo, 1971; Bezinge and others, 1973; Clague and Mathews, 1973; Mathews, 1973).

Some of the earliest jökulhlaup hydrographs were produced in Iceland (Thórarinsson, 1939, 1953, 1957, 1974; Rist, 1955, 1967, 1973, 1976, 1984). In the same country, several eyewitness descriptions have been recorded since the mid-19th century which tell about the relative changes of flow over time in certain jökulhlaups that were being watched by inhabitants below the southern reaches of Vatnajökull glacier. Such descriptions have permitted scientists to sketch rough jökulhlaup hydrographs. In many cases, the timings of the beginning, peak and end of the flood were precisely noticed. The most exact discharge curves were derived by combining field measurements of surface velocities in river currents with calculations based on the Gauckler-Manning formula (Rist, 1955, 1967, 1973, 1976, 1984). Although the absolute discharge values were not entirely accurate, the shapes of the resulting hydrographs were relatively reliable. Although the floods were over, the mean rate of drainage from the reservoir through the glacier could in some cases be computed from the observed time length of the flood and the total volume loss from lake storage, insofar as it was possible to derive this volume loss from the mean area of the lake and the drop in its surface, as monitored by level sensors or indicated by shoreline elevations (e.g. Björnsson, 1988, 1992).

While a wide variety of flood patterns have been observed in Iceland, some characteristics seem to hold in general (Björnsson, 1975, 1992, 2002; Jóhannesson, 2002). For one thing, moderate or small floods from ice-dammed marginal lakes typically emerge at the glacier terminus from a single tunnel; in addition, they rise slowly (approximately exponentially) over a period lasting from several days up to 2-3 weeks before they peak, after which they usually end in $<1$ week. In general, large floods rise faster than smaller ones and are of shorter duration. If the discharge rate from the reservoir exceeds a certain limit $\left(\sim 3000 \mathrm{~m}^{3} \mathrm{~s}^{-1}\right.$ for Grímsvötn jökulhlaups), the flood diverges under the glacier, so that water ends up exiting from more than one tunnel at the glacier terminus (Thórarinsson, 1974; Björnsson, 2002). While also regarded as rising exponentially, the major known jökulhlaups which occurred through the first three decades of the 20th century all originated from the subglacial lake Grímsvötn and emerged at the glacier terminus not from one but from $\sim 10-15$ high-capacity tunnels (as observed after the flood ended). On the other hand, it was clear that not every tunnel started carrying water simultaneously and that the main water volume was being carried by only three or four of the clearly developed tunnels (Björnsson, 1974, 1988; Thórarinsson, 1974). The greatest such Grímsvötn floods peaked in $<3$ days. Many of them were reported to break off icebergs when gushing out of ice tunnels at the terminus.

Reports extant since the 19th century, however, caused some confusion in the scientific literature as to whether exponentially rising discharge could be called representative for Grímsvötn jökulhlaups. The reason was that these outbursts had occasionally been reported to rise to extreme discharges in only 1 or 2 days (e.g. in 1861, 1867 and 1892, and even in 1938), with outbursts gushing forth all along the glacier margin, breaking up the snout across long intervals and scattering icebergs over the outwash plain, in addition to emerging well above the terminus through crevasses and fountains in order to stream down-glacier on the ice surface and fall over the snout. This last phenomenon, in which water spouted up through ice up to several hundred metres thick, indicated extremely high water pressures, accompanied by hydraulic fracturing of the glacier. Nowadays we realize that there is a quite distinct category of major jökulhlaups which contrast with the classic description of exponentially rising floods. The first Grímsvötn outburst of this major jökulhlaup type that was monitored in detail took place in 1996, when modern observations succeeded in providing insights into this type of flood (Björnsson, 1997, 2002; Snorrason and others, 1997). Rushing out violently across the whole extent of the glacier margin, outbursts of this category are also known to have occurred during the huge historical eruptions of the Katla volcano in Mýrdalsjökull. Still another instance to note is that of the Skaftá river jökulhlaups, which originate from two cauldrons in northwest Vatnajökull. These floods often increase rapidly, over 1-3 days, and recede slowly, over 1-2 weeks (Björnsson, 1977); there are, however, other types of Skaftá floods which have no distinct discharge peak but maintain a strong, stable current for up to 2 weeks before terminating. 


\section{EARLY PHENOMENOLOGICAL DESCRIPTIONS OF JÖKULHLAUPS: INITIATION AND DRAINAGE}

Glacial meltwater had long been noticed repeatedly to accumulate and escape in floods from ice-dammed lakes. In the pioneering days of glaciology, when scientists were most aware of the geometry of the particular lake and ice dam and of lake level fluctuations, they faced the elusive problem of what might initiate such floods. A factor they soon observed was that only in rare cases (cold-based glaciers) did the prefloodwater level reach high enough to overflow the ice barrier. Thus a general agreement had long prevailed that floods started because the ice barrier began to float when the lake level reached nine-tenths of barrier height (Thórarinsson, 1939; Liestøl, 1956). One logical argument against this hypothesis, however, was that lake outflow should concurrently stop as soon as the water level fell below nine-tenths of the ice dam's height. Subsequently the lake would refill and a new release be triggered, ensuring that the lake would continually remain more or less full. Speculation that water might escape through subglacial tunnels which stayed open permanently was rejected after ice tunnels at glacier margins were observed to close soon after a lake drained; moreover, the viscous properties of ice were being elucidated at about the same time (Haefeli, 1952). The hypothesis was advanced by Glen (1954) that water with sufficient hydrostatic head, enough to exceed that of the ice dam, might escape from lakes by causing plastic deformation of the ice and expanding tiny passageways, forcing some conduit to open out of the lake below the ice dam and then greatly enlarging it. However, this explanation required a basal water pressure higher than the overburden of the ice dam.

As early as 1956, Liestøl (1956, p.123-125, 145) suggested that when a lake reaches

a certain critical level [though lower than required for flotation] ... owing to the movement of the ice along an uneven basement, passages for the water will also easily form ... [and if] the water from the lake has in some way forced a small passage beneath the ice, it will, by melting, be able to extend and keep open a tunnel ... [and this will lead to] an accelerating widening of the tunnel. This appears to be in good agreement with water flow curves from the glacier lake ... [T] he relative widening of the tunnel is proportional to the penetrating water quantity.

Liestøl added that the heat for melting would be supplied by the potential energy of the dammed water, which would be transformed into heat by friction in the tunnel and would act together with sensible heat from the lake. By this time, lake water temperatures ranging from 0 to $2^{\circ} \mathrm{C}$ had been reported in Norway and Canada (Liestøl, 1956; Gilbert, 1972).

Based on field observations of flood discharge from an ice-dammed lake and on theoretical calculations of flow through subglacial conduits, Mathews (1973) concluded that the ice tunnel transporting floodwater was indeed enlarged by melting due to the frictional heat transmitted from potential energy in the lake reservoir. Mathews thereby concurred with Liestøl; moreover, Mathews supported his own model by calculating the heat transfer during turbulent water flow through an ice tunnel (to this end introducing to glaciology an engineering pipe-flow formula originally cited by McAdams, 1951). Above all, Mathews suggested a faster production of frictional heat than was necessary for melting out such an ice tunnel and predicted that water would flow out of the tunnel at temperatures above the melting point.

Geometrical data from Norway, Iceland and Canada indicated that floating the ice dam was indeed not a prerequisite for the initiation of jökulhlaups from marginal lakes (Liestøl, 1956; Mathews, 1973; Björnsson, 1974, 1976, 1988). An example of such observations was one of the longest available records of jökulhlaup cycles, which included $>20$ events over the last 80 years and related to the subglacial Icelandic lake Grímsvötn, located in the middle of Vatnajökull. Studies of water accumulation and drainage at this lake strongly supported the above-mentioned phenomenological ideas on jökulhlaups, as well as recent scientific advances in understanding their physics. All of this warrants the following brief description of the site.

Grímsvötn lake is situated beneath a depression in the glacier surface, $300 \mathrm{~m}$ deep and $10 \mathrm{~km}$ wide. This depression has been created by subglacial geothermal activity which continuously melts the ice there, creating meltwater that is trapped under the depressed glacier surface by an ice dam. The ice cover floating on the lake is normally $250 \mathrm{~m}$ thick. As a prelude to a jökulhlaup, ice moves into the Grímsvötn depression and melts, gradually expanding the subglacial water reservoir and increasing the basal water pressure so that the ice cover is lifted upwards $\left(10-15 \mathrm{~m} \mathrm{a}^{-1}\right.$ and typically $80-110 \mathrm{~m}$ altogether). However, before the water pressure exerted by the lake becomes great enough to lift the ice dam around the lake (i.e. when the water surface is still $60-70 \mathrm{~m}$ lower than would be required for a simple flotation of the ice dam: cf. Björnsson, 1974, 1988; Fowler, 1999), a connection outwards starts to open somewhere under the ice dam, breaking the hydraulic seal, and water begins to drain slowly out of the lake at the base of the ice dam and to flow down-glacier, at subglacial levels. The discharge through the opening conduits increases to the point when deformation of the outlets exceeds their enlargement by melting, as proposed by Liestøl (1956) and Mathews (1973). At this point, the lake becomes sealed off again, before actually emptying, and water begins to accumulate once more until the next jökulhlaup starts. This cycle of Grímsvötn jökulhlaups has typically occurred at 4-10 year intervals, with the jökulhlaups flowing a distance of $\sim 50 \mathrm{~km}$ beneath the ice before arriving at the glacier terminus of Skeiðarárjökull and bursting out onto the outwash plain, Skeiðarársandur. The most massive of the major Grímsvötn floods have inundated the entire outwash plain of Skeiðarársandur, which is $1000 \mathrm{~km}^{2}$ in size.

Jökulhlaups from Grímsvötn occur at any time of the year, and sudden changes in subglacial drainage due to surface melting generally do not trigger these floods. The onset of flood-scale drainage is marked by the ice quaking and the lake level subsiding, and the arrival of lake water at the glacier margin can be identified by a sulphurous odour in the glacial river. The temperature of floodwater emerging at the glacier terminus has repeatedly been measured at the melting point (Rist, 1955), which indicates that all the thermal energy has been expended en route in order to melt the surrounding ice. Based on the long-term record of lake levels, the elevation at which a jökulhlaup will begin can be predicted with some precision.

Only in one case has the lake level been observed to rise until floating the ice dam off its bed. This was subsequent to the rapid filling of the Grímsvötn lake with major discharges of meltwater from the Gjálp subglacial eruption of 1996 
(Guðmundsson and others, 1997). Only 7 months earlier (March 1996) a slowly rising jökulhlaup had taken place in which the passageways under the ice dam opened gradually, at water pressures lower than those that would have been capable of floating the dam. Since the time interval after this smaller jökulhlaup was so short, the subglacial drainage system under the ice dam was completely sealed, and the lake level managed to rise enough to float the ice dam and initiate the flood in that manner. In this unusual instance of ice dam flotation, the jökulhlaup discharge hydrograph rose faster than can be explained by the expansion of conduits through mere melting (see more discussion on this below).

The temperatures in Grímsvötn lake were first measured in the late 1980s (Björnsson, 1988, 1992). Typically, lake water stays close to the melting point despite the lake being situated within a caldera of the highly active Grímsvötn central volcano. Warm water and steam melting the surrounding glacial ice are transmitted upwards through hydrothermal vents that are mainly located at ring fractures along the surrounding caldera rims (as expressed by small ice cauldrons on the glacier surface). Before entering the lake, which lies in the centre of the caldera, such meltwater cools down to temperatures near the melting point (confirmed at various lake depths by temperature measurements of the Science Institute, University of Iceland; see Björnsson, 1992). Between the hydrothermal vents, cold water percolates down to a shallow magma chamber which maintains the geothermal activity. Also to be noted is how lake water density (calculated on the basis of chemical measurements) increases with depth, a factor which inhibits thermal convection through the lake. Chemical analyses show that the concentration of magnesium in Grímsvötn water resembles that in cold groundwater typical for Iceland (Björnsson and Kristmannsdóttir, 1984).

Yet another special factor, however, is that during volcanic eruptions in the Grímsvötn region, temperatures in the lake may temporarily rise well above the melting point due to inflowing warm meltwater from the eruption site. This happened during the 1996 Gjálp eruption (Guðmundsson and others, 1997; Björnsson, 2002) and may have occurred on previous occasions, such as in 1938 when a similar subglacial eruption took place somewhat north of the lake, at the same location as in 1996.

\section{THE DAWN OF JÖKULHLAUP THEORY}

During the early 1970s, the understanding of jökulhlaups profited from advances in theoretical glaciology. Weertman (1972) reviewed and extended an elementary theory of water flow at the base of a glacier or ice sheet. For his part, Shreve (1972) described water movements in glaciers and defined the hydraulic gradient driving water through the glacier in relation to its geometry. Röthlisberger (1972) theoretically analysed the water pressure in intra- and subglacial channels while they are being enlarged by frictional melting but are being simultaneously constricted by the deformation of the overburden ice seeking to constrict the passageway. Thus he presented conduit discharge as a function of the hydraulic gradient and of the conduit's size, shape and wall roughness. In Röthlisberger's model, a conduit draining a limited water source may be able to maintain a stable equilibrium because the overburden pressure can counteract and balance the channel's expansion due to melting.
This progressive period of theoretical glacier hydrology culminated in the work of Nye (1976). Nye formulated a general theory of time-dependent, turbulent water flow passing through a single water-filled intraglacial tunnel of a given roughness and being driven by a certain hydraulic gradient, which was related to flow velocity through the Gauckler-Manning formula. Nye described the current's energy and mass, noting the transport of thermal energy to where it melts the tunnel walls, considered the geometry of the ice tunnel and included the water contributed to the flow by the melting tunnel walls.

Nye's thesis became the basis for his jökulhlaup theory, according to which the drainage of an ice-dammed lake is controlled by the enlargement of a single ice conduit located at the glacier base. The lake discharge is governed by the lake level (which determines the hydraulic gradient), and developments in channel size are coupled to melting rates at channel walls through the dissipation of potential energy. Because the pressure head, i.e. the pressure drop from the source to the glacier snout, stays nearly constant, a voluminous reservoir does not drain by steady flow. Instead, the tunnel expands by positive feedback, with the current producing frictional heat which causes further tunnel expansion and so forth. The recession stage of the hydrograph sets in when tunnel deformation begins to exceed tunnel enlargement by melting. Finally, the jökulhlaup is terminated by conduit closure or the emptying of the reservoir.

Nye (1976) was able to test his theory on a typical, slowrising jökulhlaup which occurred from Grímsvötn in 1972. This flood exited through three river outlets, although the main outlet was the river Skeiðará. Nye assumed that the flood drained through a single, straight, cylindrical tunnel with uniform geometry from the altitude of the lake surface down to that of the glacier margin. Since the temperature of jökulhlaup water draining from the glacier had been observed to lie at the melting point (Rist, 1955), Nye assumed that the frictional heat generated by the flowing water was transferred instantaneously to the encasing ice so that the tunnel water temperature would always remain near the local pressure-melting point. He also postulated the lake temperature to lie at the melting point and, during the ascending phase up to peak flood discharge, neglected any closure of the subglacial tunnel due to ice overburden. Nye reduced the full system of his model's partial differential equations to ordinary differential equations and, with some simplifying assumptions, derived an analytical solution which predicted the discharge to rise asymptotically with time as $Q(t) \propto(1 / t)^{4}$ (where $t=0$ represented the length of time for $Q$ to approach infinity). This simulation corresponded well with the discharge rate measured on the rising limb of the Grímsvötn jökulhlaup of 1972 (Rist, 1973).

\section{ENHANCING NYE'S CLASSIC THEORY OF JÖKULHLAUPS}

Not many years passed until Nye's (1976) jökulhlaup model was enhanced by Spring and Hutter $(1981,1982)$ and Clarke (1982), allowing it to account also for reservoir temperatures, heat transfer in the tunnel, and the geometry of both the lake and the subglacial pathway. Spring and Hutter (1981) were able to solve their comprehensive set of equations (similar to the full equations derived by Nye) and accommodate a numerical analysis of Grímsvötn jökulhlaups without resorting to simplifying assumptions, 
as Nye did. Spring and Hutter obtained the most realistic fit to the 1972 Grímsvötn hydrograph by assuming that the temperature of water exiting the lake increased from the melting point at flood commencement to $4^{\circ} \mathrm{C}$ at peak discharge, then fell back to its original level in only 1 day and thereby facilitated an abrupt tunnel closure. Although relevant Grímsvötn temperatures had not been measured at that time, the reservoir has since been shown typically to contain only negligible sensible heat. Since there is no reason to expect the Grímsvötn lake temperature to have been higher than the melting point in 1972, the Spring and Hutter (1981) simulation may well have overestimated advected heat from the lake while underestimating the transfer of frictional heat from the current to the conduit's ice walls (applying the empirical pipe-flow equation introduced by Mathews, 1973.

An important observation supporting this inference was made in the 1996 jökulhlaup. While it started with exceptionally high thermal energy because the Grímsvötn lake had been heated up to $8^{\circ} \mathrm{C}$ by meltwater from the Gjálp eruption, most of this initial extra warmth had already been expended by the melting of ice along the first $6 \mathrm{~km}$ of the flood path, a graphic illustration of how fast heat can be transferred out of water flowing turbulently through intraglacial conduits (Björnsson, 1997, 2002; Jóhannesson, 2002). The rate of heat transfer from such floodwater to the surrounding ice is evidently more efficient than suggested by current jökulhlaup theory (Björnsson, 1992, 2002; Jóhannesson, 2002; Clarke, 2003). As mentioned above, the temperature of floodwater emerging at the glacier terminus has repeatedly been measured at the melting point, which indicates that all the thermal energy has been expended en route in order to melt surrounding ice.

Clarke (1982) presented a model in which he assumed that the evolution of a jökulhlaup was controlled by enlargement of the ice tunnel through melting and also by the creep closure of a single bottleneck in the water conduit at a given distance from its entrance at the lake. This model could simulate both small and large exponentially rising Grímsvötn jökulhlaups (Björnsson, 1992). Whereas the simulated ascending limbs of the hydrographs corresponded fairly well to the measured ones, the peaks in the computed graphs were nonetheless not as sharp as actual observed climaxes, and the simulated descending limbs showed little correspondence to reality. Two decades after the model mentioned above, Clarke (2003) again simulated jökulhlaups from Grímsvötn by a slightly modified form of the Spring and Hutter (1981) equations. As a flood progresses, according to Clarke (2003), the location of flow constrictions which control its magnitude may shift along the flood path, with the bottleneck that controls flow through the tunnel being located near the conduit outlet in early stages of the flood and in later stages shifting to the conduit inlet.

\section{PRESENT STATUS AND QUESTIONS OF JÖKULHLAUP SCIENCE}

Although the classical jökulhlaup theory seemed successfully to simulate exponentially rising jökulhlaups, especially through later theory enhancements, this model was well known not to describe other types of glacial outburst floods. This shortcoming was pointed out early on in regard to Skaftá jökulhlaups (Björnsson, 1977, 1992). The hydrographs of Skaftá jökulhlaups present different patterns which suggest drainage systems contrasting with those which empty the nearby Grímsvötn. One tentative suggestion for the often speedy rises of Skaftá jökulhlaups was that the reservoir temperature might be well above the melting point, which was in fact suspected because, in contrast to Grímsvötn, this lake is situated over a single concentrated cluster of hydrothermal vents, so that Jóhannesson and others (2007) have measured water temperatures of $4^{\circ} \mathrm{C}$. However, crevasses observed across the ice dam of the Skaftá cauldron after jökulhlaups were over (and sparse ice surface elevation data over the cauldron centre) suggested that these floods may be triggered when the ice dam starts to float. High water pressures have been witnessed early in the floods as water surfaced in trough crevasses and moulins close to the glacier margin and streamed down the glacier surface. Floating the ice dam allows space for water to form a basal sheet flow which soon feeds into more confined conduits and rapidly reaches a peak. However, the slowness of recession after this peak suggests that much of the floodwater spreads out beneath the glacier, where it only gradually collects into the Skaftá river outlet. Frequently, by the time of peak discharge, only $25 \%$ of the total flood volume has drained out of the glacier (Björnsson, $1977,2002)$. Guesswork on the reasons is further complicated by occasional jökulhlaups from the Skaftá cauldrons which rise slowly and oddly maintain a relatively constant discharge for days, indicating that in their cases a stable drainage system is carrying the flow, without any highcapacity tunnel drainage. This assumption is supported by an interferometric synthetic aperture radar (InSAR) analysis of ice-flow fields (following the ERS-1/ERS-2 tandem mission) which indicated that Skaftá jökulhlaups have reduced ice coupling with the glacier bed and thereby increased ice sliding fourfold in the western Vatnajökull bed. The area affected was $9 \mathrm{~km}$ wide, a breadth indicating that initial sheet flow evolved during the jökulhlaup into conduit flow (Magnússon and others, 2007). The surface velocity of the glacier increased 2 days before the flood reached the terminus, implying an average subglacial water flow speed of $0.5 \mathrm{~m} \mathrm{~s}^{-1}$.

In 1996, 20 years after the publication of Nye's (1976) classical jökulhlaup theory and its successful simulation of the 1972 exponentially rising Grímsvötn hydrograph, a rapidly rising Grímsvötn jökulhlaup (already mentioned above) was for the first time monitored in detail, with accurate measurements of the lake discharge curve. The 1996 observations provided insights into a contrasting pattern of Grímsvötn outbursts which previously had only been vaguely inferred from 19th-century resident accounts. At the initiation of this jökulhlaup, the lake had already reached an unprecedented level, sufficient to float the ice dam, and icequakes marked the onset of lake drainage. Rather than initial drainage from the lake being localized in one narrow conduit, however, the water was released as a sheet flow, suddenly surging downhill and pushing a subglacial pressure wave which exceeded the ice overburden and lifted the glacier up along the flow path. Thus, when discharge from the lake finally began, it increased quickly in a linear fashion to produce the most rapid jökulhlaup ever recorded from Grímsvötn. A flood wave emerged 10.5 hours later from the glacier margin $(50 \mathrm{~km}$ down-glacier), with the delay between the onset of reservoir drainage and the arrival of floodwater at the glacier terminus implying the accumulation of $0.6 \mathrm{~km}^{3}$ of water under the 
glacier before the flood broke out at the margin. While the initial outbursts of floodwater at the terminus spread unchannelized across the glacier margin, this type of outflow was soon replaced by drainage through highcapacity conduits (Björnsson, 1997, 2002; Snorrason and others, 1997; Jóhannesson, 2002). The enlargement of these conduits as they melted through the frictional heat of the flowing water was nonetheless only able to account for a portion $\left(0.01 \mathrm{~km}^{3}, \sim 2 \%\right)$ of the required total conduit volume. Thus, this jökulhlaup was clearly propagated through subglacial pathways that were expanded by the lifting and deformation of glacier ice, due to water pressures exceeding the overburden pressures. Extremely high basal water pressures caused hydrofracturing of the ice, so that water forced its way englacially from the base of the ice to its surface, and supraglacial fountains erupted in areas near the terminus even in places where the ice was several hundred metres thick. Escaping at the margin of Skeiðarárjökull (at $100 \mathrm{~m}$ a.s.l.), the massive, quickly arriving water quantities soon inundated nearly all of the flood plain, Skeiðarársandur. Within a period of only 40 hours, moreover, $3.2 \mathrm{~km}^{3}$ of water had already drained out.

It was impossible to explain this flood's characteristics through classic theory, since the discharge in this jökulhlaup increased much faster than could be explained by conduit expansion through melting (Björnsson, 1997, 2002; Roberts and others, 2000; Björnsson and others, 2001; Jóhannesson, 2002). The solution was therefore that Flowers and others (2004) managed to simulate the rapid rise of the 1996 jökulhlaup by combining subglacial flow through both a sheet and conduits. For this pattern of outburst, they described a one-dimensional flowline model that couples water transport in a sheet-like subglacial layer (described by reduced Navier-Stokes equations) with that through icewalled conduits, following the approach of Spring and Hutter (1981, 1982). In doing so, Flowers and others (2004) adopted Nye's (1976) simplification of instantaneous heat transfer, producing a model in which a laminar/turbulent water sheet and a system of ice-walled conduits of a given spacing coexist in a coupled system and nourish each other, with water exchanges between them depending on the relative sheet and conduit pressures. This model allows for local glacier uplift which hydraulically increases the capacity of the sheet drainage system. As a pulse of pressurized water is injected into the bed, an elastic ice flexure occurs that can be described around the peak uplift by a Gaussian function (see Flowers and Clarke, 2000, 2002). This uplift is controlled solely by hydrological and geometrical variables which the model has parameterized to describe the response of a subglacial drainage basin to sudden water inputs from the glacier surface, although it may only inadequately describe the violent injection of a jökulhlaup. Floodwater is perceived in the model as being initially propagated in a turbulent subglacial sheet along the length of the outlet glacier which soon creates and starts to feed a quickly evolving system of ice-walled conduits along the flood path. Speedy conduit growth is facilitated by the potential distribution of water sources along the whole length of the flood path. The picture in this model contrasted with the classical jökulhlaup image of tunnel enlargement and flood evolution being decided solely by the water feeding into the lake entrance of an ice tunnel, with this water input being in turn determined by lake levels, and lake drainage being controlled by the enlargement of the single conduit.
By reproducing the discharge pattern of a rapidly rising jökulhlaup, the model of Flowers and others (2004) buttressed the opinion that pressurized floodwater propagates in a turbulent subglacial sheet which subsequently forms and expands a system of high-capacity conduits. Nonetheless, more precise explanation is still lacking for how the subglacial pathway becomes enlarged by the various factors of lifting, deformation, frictional melting and hydraulic fracturing of the ice due to water pressures higher than overburden pressures.

One last complication might be added here to illustrate the challenge of comprehending Grímsvötn jökulhlaups. In the small jökulhlaup of March 1996 (7 months before the catastrophic flood), drainage occurred with an exponentially rising discharge. Although this alone could theoretically be described by tunnel flow, the velocity of the neighbouring outlet glacier, Skeiðarárjökull, was observed to increase twoto threefold over an $8 \mathrm{~km}$ wide area (Magnússon and others, 2007). This midwinter increase in sliding can only be explained by basal lubrication due to jökulhlaup water spreading out under greater parts of the overall glacier, Vatnajökull. On this occasion, a considerable temporal subglacial storage was observed, connected with a glacial lift of up to $15 \mathrm{~cm} \mathrm{~d}^{-1}$.

During the past 10 years, the understanding of jökulhlaup complexity has been considerably aided by comprehensive field studies of the processes occurring before, during and after jökulhlaups at Hidden Creek Lake, Alaska, USA (Anderson and others, 2003, 2005; Walder and others, 2005, 2006), and Gornersee, Switzerland (Huss and others, 2007; Sugiyamo and others, 2008; Walter, 2009; Werde and Funk 2009; Riesen and others, 2010). These studies have provided data for testing present and future jökulhlaup models with an accuracy heretofore impossible, as regards drainage patterns, water storage during the flood and the complex relationships between lake levels and drainage initiation mechanisms.

\section{AN EXCITING FUTURE}

The study of jökulhlaups has significant and perhaps even growing importance, both for society and pure science. In the European Alps (Werder and others, 2010) and the Himalaya (Hewitt, 1982; Yamada, 1998; Richardson and Reynolds, 2000), new glacial lakes have begun to form and flood hazards have multiplied in previously secure areas, as a consequence of global warming. Furthermore, work on Merzbacher lake, Kyrgyzstan (Ng and others, 2007; Ng and Liu, 2009), has linked climatic forcing to jökulhlaup discharge. In Greenland, one consequence is the dumping of water from supraglacial lakes down to the basal hydrological system, which adds to subglacial lubrication and may increase sliding (e.g. Das and others, 2008; Pimentel and Flowers, 2010; Schoof, 2010). Beneath Antarctic ice, the same phenomenon appears significant for water drainage from one lake to another (e.g. Wingham and others, 2006; Fricker and others, 2007; Stearns and others, 2008). Through dynamic exchanges between purer and more immediately practical science, studying the physics of these developments and of modern glacial floods of larger magnitudes may provide fundamental insights into palaeofloods of the late Pleistocene and early Holocene (e.g. Bretz, 1925a,b, 1969; Clarke and others, 1984, 2003; Baker and Bunker, 1985; Baker and others, 1993; Benn and Evans, 2006). By releasing 
enormous amounts of fresh water into the ocean, these huge floods may have altered deep-water circulation and the global climate (e.g. Broecker, 2003; Clarke and others, 2003). In this respect, the glacial floods of today may become a key to the past, and the converse.

\section{REFLECTIONS AND OUTLOOK}

Today's understanding of jökulhlaups has achieved its position by phenomenological descriptions of observed processes, combined with theoretical analyses based on the physics of glacier hydrology. This culminated in Nye's classical theory, which explained exponentially rising jökulhlaups. It has continued to serve as a foundation for further jökulhlaup studies and gradually allowed glaciologists to clarify the more complicated overall picture as new information was gathered, thus helping evidence and theory to progress hand in hand. This dialectic resulted in a step-bystep splitting of the complex puzzle of varying jökulhlaup patterns into sub-problems which were distinct enough to be tackled apart from each other, for instance when more detailed information was collected on outburst floods that did not conform to the classical jökulhlaup model. Looking towards an exciting scientific future, the study of jökulhlaups will surely continue to progress through the interplay of new phenomenological observations and theoretical insights.

Many challenging problems in this field require further exploration. The linkage of jökulhlaup initiation to the structure of the hydrological system below the ice dam is still a puzzle even if some facts have been clarified. We now know that the release of meltwater from glacial lakes may begin through either of two different conduit-opening mechanisms and that subsequent drainage from the lake occurs according to either of two different patterns. On the one hand, drainage can begin at pressures lower than the ice overburden and pass through conduits that expand slowly over days or weeks due to melting of the ice walls by frictional heat in the flowing water and sensible stored reservoir warmth. On the other hand, the lake level may rise until it becomes capable of lifting the ice dam, whereupon water pressure in excess of the ice overburden pries open waterways and widens any gaps. In this case, the flood commences as a turbulent subglacial sheet which is distributed across the glacier and serves as a tool for rapid conduit development along the flood path. Some of the first passageways are then quickly able to develop into highcapacity ice tunnels. As the turbulent subglacial water sheet interacts with the nascent system of conduits, discharge rises faster than can be accommodated by conduit melting, and the glacier ice is shoved upwards along the flow path to make space for the water.

Even if current theoretical models have been able to reproduce different jökulhlaup patterns according to the discharge patterns observed at glacier termini, jökulhlaup science still faces inconsistencies between our present theoretical knowledge and the observations of drainage behaviour along the subglacial flow path. Therefore, current models may reconstruct discharge curves while not describing all the factual hydraulic and glaciodynamic processes of each jökulhlaup.

A viable description of jökulhlaup mechanisms demands more research into the rate of heat transfer from floodwater to the surrounding ice, the impact of sudden massive jökulhlaup inputs into subglacial drainage systems, and the expansion of ice tunnels by lifting, deformation, and hydraulic fracturing of the glacier, as induced by a water pressure higher than the overburden pressure.

\section{ACKNOWLEDGEMENTS}

I am grateful to P. Vogler for improving the English text of the manuscript. A critical assessment by an anonymous reviewer and the editor, D. Rippin, led to significant manuscript improvements.

\section{REFERENCES}

Anderson, R.S., J.S. Walder, S.P. Anderson, D.C. Trabant and A.G. Fountain. 2005. The dynamic response of Kennicott Glacier, Alaska, USA, to the Hidden Creek Lake outburst flood. Ann. Glaciol., 40, 237-242.

Anderson, S.P. and 6 others. 2003. Integrated hydrologic and hydrochemical observations of Hidden Creek Lake jökulhlaups, Kennicott Glacier, Alaska. J. Geophys. Res., 108(F1), 6003. (10.1029/2002JF000004.)

Baker, V.R. 1973. Paleohydrology and sedimentology of Lake Missoula flooding in eastern Washington. Boulder, CO, Geological Society of America. (GSA Special Paper 144.)

Baker, V.R. and R.C. Bunker. 1985. Cataclysmic late Pleistocene flooding from glacial Lake Missoula: a review. Quat. Sci. Rev., $4(1), 1-41$.

Baker, V.R., G. Benito and A.N. Rudoy. 1993. Paleohydrology of Late Pleistocene superflooding, Altay Mountains, Siberia. Science, 259(5093), 348-350.

Benn, D.I. and D.J.A. Evans. 2006. Subglacial megafloods: outrageous hypothesis or just outrageous? In Knight, P.G., ed. Glacier science and environmental change. Maldon, MA, Blackwell.

Bezinge, A., J.P. Perreten and F. Schafer. 1973. Phénomènes du lac glaciaire du Gorner. IASH Publ. 95 (Symposium at Cambridge 1969 - Hydrology of Glaciers), 65-78.

Björnsson, H. 1974. Explanation of jökulhlaups from Grímsvötn, Vatnajökull, Iceland. Jökull, 24, 1-26.

Björnsson, H. 1975. Subglacial water reservoirs, jökulhlaups and volcanic eruptions. Jökull, 25, 1-14.

Björnsson, H. 1976. Marginal and supraglacial lakes in Iceland. Jökull, 26, 40-51.

Björnsson, H. 1977. The cause of jökulhlaups in the Skaftá river. Jökull, 27, 71-78.

Björnsson, H. 1988. Hydrology of ice caps in volcanic regions. Vísindafélag Ísl. Rit. 45.

Björnsson, H. 1992. Jökulhlaups in Iceland: prediction, characteristics and simulation. Ann. Glaciol., 16, 95-106.

Björnsson, H. 1997. Grímsvatnahlaup fyrr og nú. In Haraldsson, H., ed. Vatnajökull: gos og hlaup 1996. Reykjavík, Vegagerdin, 61-77.

Björnsson, H. 2003. Subglacial lakes and jökulhlaups in Iceland. Global Planet. Change, 35(3-4), 255-271.

Björnsson, H. and H. Kristmannsdóttir. 1984. The Grímsvötn geothermal area, Vatnajökull, Iceland. Jökull, 34, 25-50.

Björnsson, H., H. Rott, S. Gudmundsson, A. Fischer, A. Siegel and M.T. Gudmundsson. 2001. Glacier-volcano interactions deduced by SAR interferometry. J. Glaciol., 47(156), 58-70.

Bretz, J.H. 1925a. The Spokane flood beyond the Channeled Scabland. J. Geol., 33(2), 97-115.

Bretz, J.H. 1925b. The Spokane flood beyond the Channeled Scabland. II. J. Geol., 33(3), 236-259.

Bretz, J.H. 1969. The Lake Missoula floods and the Channeled Scabland. J. Geol., 77(5), 505-543.

Broecker, W.S. 2003. Does the trigger for abrupt climate change reside in the ocean or in the atmosphere? Science, 300(5625), 1519-1522. 
Chow, V.T. 1959. Open-channel hydraulics. New York, McGrawHill.

Clague, J.J. and W.H. Mathews. 1973. The magnitude of jökul hlaups. J. Glaciol., 12(66), 501-504.

Clarke, G., D. Leverington, J. Teller and A. Dyke. 2003. Superlakes, megaflood, and abrupt climate change. Science, 301(5635), 922-923.

Clarke, G.K.C. 1982. Glacier outburst floods from 'Hazard Lake', Yukon Territory, and the problem of flood magnitude prediction. J. Glaciol., 28(98), 3-21.

Clarke, G.K.C. 2003. Hydraulics of subglacial outburst floods: new insights from the Spring-Hutter formulation. J. Glaciol., 49(165), 299-313.

Clarke, G.K.C., W.H. Mathews and R.T. Pack. 1984. Outburst floods from Glacial Lake Missoula. Quat. Res., 22(3), 289-299.

Das, S.B. and 6 others. 2008. Fracture propagation to the base of the Greenland Ice Sheet during supraglacial lake drainage. Science, 320(5877), 778-781.

Flowers, G.E. and G.K.C. Clarke. 2000. An integrated modelling approach to understanding subglacial hydraulic release events. Ann. Glaciol., 31, 222-228.

Flowers, G.E. and G.K.C. Clarke. 2002. A multicomponent coupled model of glacier hydrology: 1 . Theory and synthetic examples. J. Geophys. Res., 107(B11), 2287. (10.1029/2001JB001122.)

Flowers, G.E., H. Björnsson, R. Pálsson and G.K.C. Clarke. 2004. A coupled sheet-conduit mechanism for jökulhlaup propagation. Geophys. Res. Lett., 31(5), L05401. (10.1029/2003GL019088.)

Fowler, A.C. 1999. Breaking the seal at Grímsvötn, Iceland. J. Glaciol., 45(151), 506-516.

Fricker, H.A., T. Scambos, R. Bindschadler and L. Padman. 2007. An active subglacial water system in West Antarctica mapped from space. Science, 315(5818), 1544-1548.

Gilbert, R. 1971. Observations on ice-dammed Summit Lake, British Columbia, Canada. J. Glaciol., 10(60), 351-356.

Gilbert, R. 1972. Drainings of ice-dammed Summit Lake, British Columbia. Ottawa, Ont., Environment Canada. Inland Waters Directorate. Water Resources Branch. (IWD Scientific Series 20.)

Glen, J.W. 1954. The stability of ice-dammed lakes and other waterfilled holes in glaciers. J. Glaciol., 2(15), 316-318.

Guðmundsson, M.T., F. Sigmundsson and H. Björnsson. 1997. Icevolcano interaction of the 1996 Gjálp subglacial eruption, Vatnajökull, Iceland. Nature, 389(6654), 954-957.

Haefeli, R. 1952. Observations on the quasi-viscous behaviour of ice in a tunnel in the Z'Mutt Glacier. J. Glaciol., 2(12), 94-99.

Hewitt, K. 1982. Natural dams and outburst floods of the Karakorum Himalaya. IAHS Publ. 138 (Symposium at Exeter 1982 - Hydrological Aspects of Alpine and High Mountain Areas), 259-269.

Huss, M., A. Bauder, M. Werder, M. Funk and R. Hock. 2007. Glacier-dammed lake outburst events of Gornersee, Switzerland. J. Glaciol., 53(181), 189-200.

Jóhannesson, T. 2002. Propagation of a subglacial flood wave during the initiation of a jökulhlaup. Hydrol. Sci. J., 47(3), 417-434.

Jóhannesson, T., Th. Thorsteinsson, A. Stefánsson, E.J. Gaidos and B. Einarsson. 2007. Circulation and thermodynamics in a subglacial geothermal lake under the Western Skaftá cauldron of the Vatnajökull ice cap, Iceland. Geophys. Res. Lett., 34(19), L19502. (10.1029/2007GL030686.)

Liestøl, O. 1956. Glacier dammed lakes in Norway. Nor. Geogr. Tidsskr., 15(3-4), 122-149.

Magnússon, E., H. Rott, H. Björnsson and F. Pálsson. 2007. The impact of jökulhlaups on basal sliding observed by SAR interferometry on Vatnajökull, Iceland. J. Glaciol., 53(181), 232-240.

Mathews, W.H. 1973. Record of two jökulhlaups. IASH Publ. 95 (Symposium at Cambridge 1969 - Hydrology of Glaciers), 99-110.

McAdams, W.H. 1951. Heat transmission. Second edition. New York, McGraw-Hill.

Ng, F. and S. Liu. 2009. Temporal dynamics of a jökulhlaup system. J. Glaciol., 55(192), 651-665.
Ng, F., S. Liu, B. Mavlyudov and Y. Wang. 2007. Climatic control on the peak discharge of glacier outburst floods. Geophys. Res. Lett., 34(21), L21503. (10.1029/2007GL031426.)

Nye, J.F. 1976. Water flow in glaciers: jökulhlaups, tunnels and veins. J. Glaciol., 17(76), 181-207.

Pardee, J.T. 1942. Unusual current in glacial Lake Missoula, Montana. Geol. Soc. Am. Bull., 53(11), 1569-1599.

Pimentel, S. and G.E. Flowers. 2010. A numerical study of hydrologically driven glacier dynamics and subglacial flooding. Proc. R. Soc. London, Ser. A, 467(2126), 537-558.

Post, A. and L.R. Mayo. 1971. Glacier dammed lakes and outburst floods in Alaska. USGS Hydrol. Invest. Atlas HA-455.

Richardson, S.D. and J.M. Reynolds. 2000. An overview of glacial hazards in the Himalayas. Quat. Int., 65/66(1), 31-47.

Richter, E. 1892. Urkunden über die Ausbrüche des Vernagt- und Gurglergletschers im 17. und 18. Jahrhundert. Forsch. Deut. Landes- und Volksd., 6(4), 345-440.

Riesen, P., S. Sugiyama and M. Funk. 2010. The influence of the presence and drainage of an ice-marginal lake on the flow of Gornergletscher, Switzerland. J. Glaciol., 56(196), 278-286.

Rist, S. 1955. Skeiðarárhlaup 1954. Jökull, 5, 30-36.

Rist, S. 1967. Jökulhlaups from the ice cover of Mýrdalsjökull on June 25, 1955 and January 20, 1956. Jökull, 17, 243-248.

Rist, S. 1973. Jökulhlaupaannáll 1971, 1972 og 1973. Jökull, 23, 55-60.

Rist, S. 1976. Grímsvatnahlaupið 1976. Jökull, 26, 80-90.

Rist, S. 1984. Jökulhlaupaannáll 1981, 1982 og 1983. Jökull, 34, 165-172.

Roberts, M.J., A.J. Russell, F.S. Tweed and O. Knudsen. 2000. Ice fracturing during jökulhlaups: implications for englacial floodwater routing and outlet development. Earth Surf. Process. Landf., 25(13), 1429-1446.

Röthlisberger, H. 1972. Water pressure in intra- and subglacial channels. J. Glaciol., 11(62), 177-203.

Schoof, C. 2010. Ice-sheet acceleration driven by melt supply variability. Nature, 468(7325), 803-806.

Shreve, R.L. 1972. Movement of water in glaciers. J. Glaciol., 11(62), 205-214.

Snorrason, Á. and 7 others. 1997. Hlaupið á Skeiðarársandi haustið 1996: útbreidsla, rennsli og aurburður. In Haraldsson, H., ed. Vatnajökull: gos og hlaup 1996. Reykjavík, Vegagerdin, 79-137.

Spring, U. and K. Hutter. 1981. Numerical studies of jökulhlaups. Cold Reg. Sci. Technol., 4(3), 227-244.

Spring, U. and K. Hutter. 1982. Conduit flow of a fluid through its solid phase and its application to intraglacial channel flow. Int. J. Eng. Sci., 20(2), 327-363.

Stearns, L.A., B.E. Smith and G.S. Hamilton. 2008. Increased flow speed on a large East Antarctic outlet glacier caused by subglacial floods. Nature Geosci., 1(12), 827-831.

Stotter, M. 1846. Die Gletscher des Bernagtthales in Tirol und ihre Geschichte. Innsbruck, Wagner.

Ström, K.M. 1938. The catastrophic emptying of a glacier-dammed lake in Norway 1937. Geol. Meere Binnengewässer, 2(3), 443-444.

Sugiyama, S., A. Bauder, M. Huss, P. Riesen and M. Funk. 2008. Triggering and drainage mechanisms of the 2004 glacierdammed lake outburst in Gornergletscher, Switzerland. J. Geophys. Res., 113(F4), F04019. (10.1029/2007JF000920.)

Thórarinsson, S. 1939. The ice dammed lakes of Iceland with particular reference to their values as indicators of glacier oscillations. Geogr. Ann., 21(3-4), 216-242.

Thórarinsson, S. 1953. Some new aspects of the Grímsvötn problem. J. Glaciol., 2(14), 267-275.

Thórarinsson, S. 1957. The jökulhlaup from the Katla area in 1955 compared with other jökulhlaups in Iceland. Jökull, 7, 21-25.

Thórarinsson, S. 1974. Vötnin stríð: saga Skeiðarárhlaupa og Grímsvatnagosa. Reykjavík, Bókaútgáfa Menningarsjóðs.

Walder, J.S. and 6 others. 2005. Fault-dominated deformation in an ice dam during annual filling and drainage of a marginal lake. Ann. Glaciol., 40, 174-178. 
Walder, J.S. and 6 others. 2006. Local response of a glacier to annual filling and drainage of an ice-marginal lake. J. Glaciol., 52(178), 440-450.

Walter, F. 2009. Seismic activity on Gornergletscher during Gornersee outburst floods. (PhD thesis, ETH Zürich.)

Weertman, J. 1972. General theory of water flow at the base of a glacier or ice sheet. Rev. Geophys. Space Phys., 10(1), 287-333.

Werder, M.A. and M. Funk. 2009. Dye tracing a jökulhlaup: II. Testing a jökulhlaup model against flow speeds inferred from measurements. J. Glaciol., 55(193), 899-908.
Werder, M.A., A. Bauder, M. Funk and H.-R. Keusen. 2010. Hazard assessment investigations in connection with the formation of a lake on the tongue of Unterer Grindelwaldgletscher, Bernese Alps, Switzerland. Natur. Hazards Earth Syst. Sci. (NHESS), 10(2), 227-237

Wingham, D.J., M.J. Siegert, A. Shepherd and A.S. Muir. 2006. Rapid discharge connects Antarctic subglacial lakes. Nature, 440(7087), 1033-1036.

Yamada, T. 1998. Glacier lake and its outburst flood in the Nepal Himalaya. Tokyo, Japanese Society of Snow and Ice. Data Center for Glacier Research. 